\title{
PENGAURH BEBERAPA FAKTOR TERHADAP KEPUASAN KERJA KARYAWAN PADA PT. ASAM JAWA MEDAN
}

\author{
Oleh \\ Drs. Sinar Ritonga, MS
}

\begin{abstract}
The research objective was to determine the effect of climate variables organiasi, the behavior of the leadership, motivation, and practice decision-making to terhahap job satisfaction of employees at PT. Asam Jawa Medan. The population in this study were all employees at PT. Asam Jawa field numbered 39 and all members of the sample. The analysis model is a linear regression. The results showed that organiasi climate variables, the behavior of the leadership, motivation, decision making and practice simultaneously and partially have a significant influence on employee job satisfaction at. Asam Jawa Medan
\end{abstract}

Keywords: Climate organiasi, the behavior of the leadership, motivation, and practice decision-making

\section{PENDAHULUAN}

Keberhasilan suatu organisasi untuk mencapai tujuannya ditentukan oleh banyak hal, salah satunya adalah kepemimpinan yang dibangun di dalam organisasi tersebut. Pemimpin yang sukses adalah pemimpin yang mampu menjadi kreator dan motivator bagi bawahannya dengan menciptakan suasana dan budaya kerja yang dapat memacu kepuasan kerja bawahannya. Sutopo (2011) mengemukakan bahwa iklim organisasi sebagai keseluruhan lingkungan kerja karyawan dan dibatasi oleh aturan tempat kerja karyawan baik secara langsung atau tidak langsung dan mempengaruhi kinerja karyawan dalam organisasi itu. Wirawan (2007) mengemukakan bahwa iklim ada secara objektif dalam suatu organisasi, tetapi hanya dapat digambarkan dan diukur secara tidak langsung melalui persepsi dari anggota organisasi. Dari uraian di atas jika dihubungkan dengan teori Davidson dkk (2001) bahawa iklim organisasi berhubungan dengan tujuh aspek berikut yakni: kepemimpinan dan fasilitas serta dukungan, profesional dan semangat organisasi, konflik dan ambiguitas peran, tekanan dan aturan organisasi, berbagai macam tugas dan tantangan serta otonomi, kerja sama dengan kelompok kerja dan standar kerja akan dijadikan sebagai aspek iklim organisasi dalam penyusunan skala iklim organisasi sebagai variabel bebas pertama.

Praktek pengambilan keputusan adalah proses dalam teknik untuk mempersempit pilihan pendekatan yang sistematis terhadap hakikat alternatif yang dihadapi dan mengambil tindakan yang menurut perhitungan merupakan tindakan yang paling tepat.Praktek pengambilan keputusan dalam penyelesaian masalah adalah kemampuan mendasar bagi seorang pemimpin, khususnya dalam asuhan karyawan. Tidak hanya berpengaruh pada proses pengelolaan asuhan karyawan, tetapi penting untuk meningkatkan kemampuan merencanakan perubahan. Semua karyawan pada semua tingkatan posisi harus memiliki 
kemampuan menyelesaikan masalah dan mengambil keputusan yang efektif, baik sebagai pelaksana/staf maupun sebagai pemimpin.

Penyelesaian masalah dan pengambilan keputusan bukan merupakan bentuk sinonim. Pemecahan masalah dan proses pengambilan keputusan membutuhkan pemikiran kritis dan analisis yang dapat ditingkatkan dalam praktek. Pengambilan keputusan merupakan upaya pencapaian tujuan dengan menggunakan proses yang sistematis dalam memilih alternatif. Tidak semua pengambilan keputusan dimulai dengan situasi masalah. Pemecahan masalah termasuk dalam langkah proses pengambilan keputusan, yang difokuskan untuk mencoba memecahkan masalah secepatnya. Masalah dapat digambarkan sebagai kesenjangan diantara "apa yang ada dan apa yang seharusnya $a d a^{\prime \prime}$. Pemecahan masalah dan pengambilan keputusan yang efektif diprediksi bahwa individu harus memiliki kemampuan berfikir kritis dan mengembangkan dirinya dengan adanya bimbingan dan role model di lingkungan kerjanya.

Hasibuan (2005) mendefinisikan kepuasan kerja sebagai suatu perasaan positif tentang pekerjaan seseorang yang merupakan hasil dari sebuah evaluasi karakteristiknya. Iklim organisasi yang baik seperti komunikasi antar rekan kerja dan komunikasi atasan bawahan yang baik akan mempengaruhi kepuasan kerja. Menurut Gibson dkk (2002) karyawan yang puas dalam bekerja seperti mendapatkan upah yang layak dari pekerjaannya, dukungan dan penghargaan dari atasan akan menciptakan motivasi yang tinggi pada karyawan. Iklim organisasi, kepuasan kerja, praktek pengambilan keputusan dan motivasi kerja mempunyai hubungan yang positif seperti yang dijelaskan oleh Singh dkk (2011) mengatakan iklim organisasi yang baik seperti komunikasi antar rekan kerja baik, dukungan dan penghargaan atasan sangat berpengaruh besar terhadap kepuasan kerja dan apabila motivasi kerja telah tercapai maka akan menyebabkan kepuasan kerja yang tinggi pada karyawan.

Sopiah (2008) menyatakan bahwa kepuasan kerja merupakan suatu tanggapan emosional seseorang terhadap situasi dan kondisi kerja dengan kondisi yang diharapkan dan kondisi yang sebenarnya karyawan peroleh, dan apabila hasil tidak sesuai dengan harapannya maka akan terjadi ketidakpuasan (negatif) sebaliknya apabila hasil yang didapat sesuai dengan harapan maka terjadi kepuasan (positif) pada karyawan. Hasibuan (2005) mendefinisikan kepuasan kerja adalah sikap emosional yang menyenangkan dan mencintai pekerjaannya, sikap ini dicerminkan oleh moral kerja, kedisiplinan dan prestasi kerja. Kepuasan kerja dinikmati dalam pekerjaan, luar pekerjaan, dan kombinasi dalam dan luar pekerjaan. Dari beberapa pengertian di atas maka dapat disimpulkan bahwa kepuasan kerja adalah perasaan seseorang terhadap pekerjaannya, perasaan yang menyenangkan atau tidak menyenangkan dalam pekerjaan dan sesuai atau tidak sesuai antara pekerjaan yang karyawan lakukan dengan upah atau gaji yang didapat karyawan serta harapan-harapan mengenai pengalaman dimasa mendatang yang lebih baik.

Berdasarkan penelitian pendahuluan dengan manajemen perusahaan dikemukakan bahwa dalam dua tahun terakhir (2014-2015) adanya kecenderungan penurunan kepuasan kerja karyawan yang tercermin dari penurunan produktivitas kerja, meningkatnya absensi, menurunya kehadiran tepat waktu, menurunnya keinginan kerja lembur, peningkatan turn over dari paar pegawai. Berdasarkan uraian di atas maka dilakukan penelitian apakah penurunan kepuasan kerja 
pegawai disebabkan oleh iklim organisasi, perilaku pemimpin, motivasi kerja dan praktek pengambilan keputusan.

\section{TINJAUAN PUSTAKA}

\section{Iklim Organisasi}

Menurut Arinez (2002) bahwa iklim organisasi merupakan salah satu faktor yang mempengaruhi kepuasan kerja, setiap perusahaan harus memperhatikan atau mengamati iklim kerja di lingkungan kerja karyawan agar tercipta iklim organisasi yang baik. Wirawan (2007) mendefinisikan iklim organisasi adalah persepsi anggota organisasi (secara individual dan kelompok) dan anggota yang secara tetap berhubungan dengan organisasi (misalnya pemasok, konsumen, konsultan, kontraktor) mengenai kondisi yang ada atau terjadi di lingkungan internal organisasi secara rutin, yang mempengaruhi sikap dan perilaku organisasi dan kinerja anggota organisasi yang kemudian menentukan kinerja organisasi. Singh dkk (2011) mendefinisikan iklim organisasi sebagai keseluruhan lingkungan kerja karyawan dan dibatasi oleh aturan tempat kerja karyawan baik secara langsung atau tidak langsung dan mempengaruhi kinerja karyawan dalam organisasi itu. Pendapat ini menilai bahwa melihat kondisi kerja sebagai suatu yang komperehensif sehingga mencakup segala yang ada di dalam tempat kerja tersebut. Dari beberapa pengertian yang diuraikan di atas maka dapat disimpulkan bahwa iklim organisasi sebagai persepsi anggota tentang bagaimana mereka di perlakukan oleh organisasi mereka. Menurut Davidson dkk (2001) iklim organisasi mempunyai tujuh aspek yang harus diperhatikan, yaitu : (a) kepemimpinan dan fasilitas serta dukungan (b) profesional dan semangat organisasi, (c) konflik dan ambiguitas peran (d) tekanan dan aturan organisasi, (e)berbagai macam tugas, tantangan dan otonomi (f) kerja sama dengan kelompok kerja, dan (g) standar kerja.

\section{Perilaku Pemimpin}

Perilaku pemimpin adalah suatu perilaku seseorang yang ingin memelihara hubungan-hubugan antar pribadi diantara dirinya dengan anggota-anggota kelompok atau para pengikut dengan cara membuka lebar-lebar jalur komunikasi, mendelegasikan tanggung jawab, dan memberikan kesempatan kepada bawahan untuk menggunakan potensinya. Hal semacam ini di sifati oleh dukungan sosio emosional, kesetiakawanan, dan kepercayaan bersama. Menurut Thoha (2007) ada dua bentuk perilaku pemimpin dalam suatu organisasi diantaranya adalah perilaku tugas dan perilaku hubungan. Dua bentuk perilaku tugas dan perilaku hubungan merupakan titik pusat dari konsep kepemimpinan situasional. (a) perilaku tugas adalah suatu perilaku seorang pemimpin untuk mengatur dan merumuskan peranan-peranan anggota-anggota kelompok atau para pengikut; menerangkan kegiatan yang harus dikerjakan oleh masing-masing anggota,kapan dilakukan, dimana melaksanakannya, dan bagaimana tugas-tugas itu harus dicapai, dan (b) perilaku hubungan adalah suatu perilaku seorang pemimpin yang ingin memelihara hubungan-hubungan antar pribadi diantara dirinya dengan anggota kelompok atau para pengikut dengan cara membuka lebar-lebar jalur komunikasi, mendelegasikan tanggung jawab, dan memberikan kesempatan kepada bawahan untuk menggunakan potensinya. Hal semacam ini disifati oleh dukungan sosioemosional, kesetiakawanan, dankepercayaan bersama. 
Faktor yang mempengaruhi baik buruknya hubungan antara karyawan dan pimpinannya adalah faktor sikap dan tindakan pemimpin (Gaya kepemimpinan) terhadap bawahannya. Pernyataan ini didukung oleh definisi yang dikemukakan oleh Hasibuan (2005) Gaya kepemimpinan merupakan pola khas dari perilaku yang ditunjukkan oleh pemimpin pada saat berhadapan dengan karyawannya. Dari pendapat para ahli di atas maka, dapat disimpulkan bahwa perilku pemimpin adalah sikap atau tindakan pemimpin tidak jarang menimbulkan petengkaran, perselisihan dengan karyawan dan atau diantara karyawan. Namun dapat juga berlaku sebaliknya, sikap pemimpin tersebut justru mendorong karyawannyauntuk lebih berprestasi.

\section{Teori perilaku pemimpin}

Model kepemimpinan, pada dasarnya mengandung pengertian sebagai suatu perwujutan tingkah laku dari seorang pemimpin, yang menyangkut kemampuannya dalam memimpin. Perwujutan tersebut biasanya membentuk suatu polaatau bentuk tertentu. Keduanya menyatakan bahwa pola tindakan pemimpin secara keseluruhan seperti yang telah dipersepsikan atau diacu oleh bawahan tersebut dikenal sebagai gaya kepemimpinan. Dalam melaksanakan tugas kepemimpinan mempengaruhi orang atau kelompok menuju tujuan tertentu, faktor yang mempengaruhi baik buruknya hubungan antara karyawan danpimpinannya adalah faktor sikap dan tindakan pemimpin terhadap bawahannya. Faktor- faktor yang mempengaruhi pemimpinan yaitu: (a) faktor kemampuan personal, (b) faktor Jabatan, dan (c) faktorsituasi dan kondisi.

\section{Motivasi Kerja}

Proses terjadinya motivasi dalam diri individu menurut Minner dkk dalam Tella dkk, (2007) yaitu adanya suatu kebutuhan (need), setiap individu harus memenuhi kebutuhan agar tetap mempertahankan hidupnya. Kemudian yang kedua ada dorongan (drive), individu harus memenuhi kebutuhan hidupnya, maka dari itu menyebabkan dorongan dalam diri individu untuk memenuhi kebutuhan hidupnya, sedangkan yang ketiga ada keuntungan (incentive), individu mempunyai tujuan dalam bekerja yaitu keuntungan, seperti upah, prestasi dan kekuasaan. Terdapat beberapa definisi mengenai motivasi. Gibson (1996) mendefinisikan motivasi sebagai suatu konsep yang sering digunakan untuk menggambarkan dorongan-dorongan yang timbul atau di dalam seseorang individu yang menggerakkan dan mengarahkan perilaku. Sedangakan Nawawi (2003) menyatakan motivasi adalah suatu kondisi yang mendorong atau menjadi sebab seseorang melakukan suatu perbuatan/kegiatan yang berlangsung secara sadar.

Dalam pemberian motivasi seluruh perusahaan mempunyai kesamaan tujuan untuk merangsang dan mendorong individu agar bekerja lebih giat, efisien dan efektif dalam rangka mencapai tujuan perusahaan. Ada beberapa tujuan yangdapat diperoleh dari pemberian motivasi menurut Hasibuan (2005) yaitu: (a) menigkatkan moral dan kepuasan kerja karyawan, (b) menigkatkan prestasi kerja karyawan, (c) meningkatkan kedisiplinan karyawan, (d) mempertahankan kesetabilan perusahaan, (e) mengefektifkan pengadaan karyawan, (f) menciptakan suasana dan hubungan kerja yang baik, (g) menigkatkan loyalitas, kreativitas dan partisivasi, (h) Meningkatkan tinggat kersejahteraan karyawan, (i) Menigkatkan rasa tanggung jawab keryawan terhadap tugas, (j) Menigkatkan efisiensi penggunaan alat-alat dan bahan baku. 


\section{Praktek Pengambilan Keputusan}

Praktek pengambilan keputusan adalah proses dalam teknik untuk mempersempit pilihan pendekatan yang sistematis terhadap hakikat alternatif yang dihadapi dan mengambil tindakan yang menurut perhitungan merupakan tindakan yang paling tepat.Praktek pengambilan keputusan dalam penyelesaian masalah adalah kemampuan mendasar bagi seorang pemimpin, khususnya dalam asuhan karyawan. Penyelesaian masalah dan pengambilan keputusan bukan merupakan bentuk sinonim. Pemecahan masalah dan proses pengambilan keputusan membutuhkan pemikiran kritis dan analisis yang dapat ditingkatkan dalam praktek. Pengambilan keputusan merupakan upaya pencapaian tujuan dengan menggunakan proses yang sistematis dalam memilih alternatif. Tidak semua pengambilan keputusan dimulai dengan situasi masalah. Pemecahan masalah termasuk dalam langkah proses pengambilan keputusan, yang difokuskan untuk mencoba memecahkan masalah secepatnya. Masalah dapat digambarkan sebagai kesenjangan diantara "apa yang ada dan apa yang seharusnya ada". Pemecahan masalah dan pengambilan keputusan yang efektif diprediksi bahwa individu harus memiliki kemampuan berfikir kritis dan mengembangkan dirinya dengan adanya bimbingan dan role model di lingkungan kerjanya. Ada lima hal yang perlu diperhatikan dalam praktek pengambilan keputusan : (a) dalam proses pengambilan keputusan tidak terjadi secara kebetulan, (b) pengambilan keputusan tidak dilakukan secara sembrono tapi harus berdasarkan pada sistematika tertentu, (c) masalah harus diketahui dengan jelas, (d) pemecahan masalah harus didasarkan pada fakta-fakta yang terkumpul dengan sistematis, dan (e) keputusan yang baik adalah keputusan yang telah dipilih dari berbagai alternatif yang telah dianalisa secara matang.

\section{Kepuasan Kerja}

Kepuasan kerja merupakan sikap emosional yang menyenangkan dan mencintai pekerjaannya. Sikap ini dicerminkan oleh moral kerja, kedisiplinan, dan prestasi kerja. Sopiah (2008) menyatakan bahwa kepuasan kerja merupakan suatu tanggapan emosional seseorang terhadap situasi dan kondisi kerja dengan kondisi yang diharapkan dan kondisi yang sebenarnya karyawan peroleh, dan apabila hasil tidak sesuai dengan harapannya maka akan terjadi ketidakpuasan (negatif) sebaliknya apabila hasil yang didapat sesuai dengan harapan maka terjadi kepuasan (positif) pada karyawan Hasibuan dalam (Prabu, 2005) mendefinisikan kepuasan kerja adalah sikap emosional yang menyenangkan dan mencintai pekerjaannya, sikap ini dicerminkan oleh moral kerja, kedisiplinan dan prestasi kerja. Kepuasan kerja dinikmati dalam pekerjaan, luar pekerjaan, dan kombinasi dalam dan luar pekerjaan. Luthan (dalam Tella dkk, 2007) mendefinisikan kepuasan kerja sebagai respon terhadap emosi situasi pekerjaan, Dari beberapa pengertian yang diuraikan di atas maka dapat disimpulkan bahwa kepuasan kerja adalah perasaan seseorang terhadap pekerjaannya, perasaan yang menyenangkan atau tidak menyenangkan dalam pekerjaan dan sesuai atau tidak sesuai antara pekerjaan yang karyawan lakukan dengan upah atau gaji yang didapat karyawan serta harapan-harapan mengenai pengalaman dimasa mendatang yang lebih baik. 
1. Ruang Lingkup Penelitian.

\section{METODE PENELITIAN}

Penelitian ini dilakukan untuk mengetahui pengaruh iklim organisasi, perilaku pemimpin, motivasi kerja, praktik pengambilan keputusan terhadap kepuasan kerja karyawan PT. Asam Jawa Medan.

\section{Populasi dan sampel}

Populasi dalam penelitian ini adalah seluruh karyawan pada PT. Asam Jawa Medan berjumlah 39 orang. Karena jumlah populasi dibawah 100 orang maka seluruh anggota populasi akan menjadi anggota sampel. Dengan kata lain metod pengambilan sampel yang digunakan adalah sampling jenuh atau sensus.

\section{Operasionalisasi Variabel}

Definisi operasionalisasi dari masing-masing variabel yang diteliti adalah

a. Iklim Organisasi $\left(X_{1}\right)$ adalah sebagai keseluruhan lingkungan kerja karyawan dan dibatasi oleh aturan tempat kerja karyawan baik secara langsung atau tidak langsung dan mempengaruhi kinerja karyawan dalam organisasi itu dengan indicator: kepemimpinan dan fasilitas serta dukungan, profesional dan semangat organisasi, konflik dan ambiguitas peran, tekanan dan aturan organisasi, berbagai macam tugas dan tantangan serta otonomi, kerja sama dengan kelompok kerja dan standar kerja

b. Perilaku Pemimpin $\left(X_{2}\right)$ adalah pola perilaku yang diperlihatkan orang itu pada saat mempengaruhi aktivitas orang lain seperti yang dipersepsikan orang lain dengan indikator: faktor kemampuan personal, faktor jabatan dan faktor situasi dan kondisi kerja.

c. Motivasi Kerja $\left(\mathrm{X}_{3}\right)$ adalah proses yang menjelaskan intensitas, arah dan ketekunan usaha untuk mencapai suatu tujuan dengan indicator: satisfers dan dessatisfiers.

d. Proses Pengambilan Keputusan $\left(X_{4}\right)$ adalah proses dalam teknik untuk mempersempit pilihan pendekatan yang sistematis terhadap hakikat alternatif yang dihadapi dan mengambil tindakan yang menurut perhitungan merupakan tindakan yang paling tepat dengan indikator: Faktor Internal dan faktor eksternal.

e. Kepuasan Kerja (Y) adalah perasaan seseorang terhadap pekerjaannya, perasaan yang menyenangkan atau tidak menyenangkan dalam pekerjaan dan sesuai atau tidak sesuai antara pekerjaan yang karyawan lakukan dengan upah atau gaji yang didapat karyawan serta harapan-harapan mengenai pengalaman dimasa mendatang yang lebih baik dengan indicator: upah atau bayaran, pekerjaan iti sendiri, pengawasan, teman kerja, jaminan kerja dan kesempatan promosi 
Skala pengukuran yang digunakan untuk mengukur masing-masing variabel adalah dengan menggunakan Skala Likert.

\section{Teknik Pengumpulan Data}

Metode pengumpulan data yang digunakan dalam penelitian ini adalah : (a) wawancara, (b) kuesioner, dan (c) studi dokumentasi

\section{Teknik Analisis Data}

Teknik analisis yang digunakan ialah analisis kuantitatif. Untuk menganalisis data kuantitatif dilakukan dengan bantuan software SPSS (Statistical Program for Social Sciences) versi 18,0 dengan langkah-langkah sebagai berikut:

a. Uji Validitas dan Realiabilitas.

b. Uji Asumsi Klasik yang terdiri dari: Uji Normalitas, Heteroskedastisitas, Autokorelasi, dan multikolinieritas.

c. Model Analisis

model analisis yang digunakan adalah Regresi Lininer Berganda dengan model persamaan sebagai berikut adalah $\mathrm{KK}=\mathrm{a}+\mathrm{b}_{1} \mathrm{IO}+\mathrm{b}_{2} \mathrm{PP}+\mathrm{b}_{3} \mathrm{MK}+\mathrm{b}_{4} \mathrm{PK}+\mathrm{e}$

\section{Dimana :}

$\begin{array}{ll}\mathrm{KK} & =\text { Kepuasan Kerja } \\ \mathrm{a} & =\text { Konstanta } \\ \mathrm{b}_{1} \mathrm{~b}_{2} \mathrm{~b}_{3} \mathrm{~b}_{4} & =\text { Koefisien regresi variabel bebes } \\ \mathrm{IO} & =\text { Iklim Organisasi } \\ \mathrm{PP} & =\text { Perilaku Pemimpin } \\ \mathrm{MK} & =\text { Motivasi Kerja } \\ \mathrm{PK} & =\text { Praktek Pengambilan Keputusan } \\ \mathrm{e} & =\text { Error term }\end{array}$

d. Uji Hipotesis: Uji Simultan (Uji-F) dan, Uji parsial (Uji t t), dengan kriteria ada pengaruh simultan dan parsial jika probabilitas significant dibawah 0.05 dan sebaliknya

\section{HASIL PENELITIAN DAN PEMBAHASAN}

\section{Hasil Penelitian}

\section{a. Uji Validitas dan Realiabilitas}

Hasil pengujian terhadap validitas dan realiabilitas menunjukkan bahwa indikator iklim organiasi, perilaku pimpinan, motivasi kerja, dan praktek pengambilan keputusan, kepuasan kerja karyawan Pada PT. Asam Jawa Medan sudah valid dan reliable, karena nilai korelasi hitung telah lebih besar dari 0,30, dan nilai Alpha Cronbach telah lebih besar dari 0,60.

\section{b. Pengujian Asumsi Klasik}

Hasil pengujian terhadap asumsi klasik menunjukkan bahwa asumsi normalitas telah dipenuhi hal ini dutunjukkan dari Jargue-Bera 0,682785 dengan probabilitas 0,710780. Berdasarkan nilai statistic Durbin-Watson, $\mathrm{d}=1,823$ sedangkan untuk jumlah sampel $\mathrm{n}=35, \mathrm{k}=5$ dan tingkat signifikansi $\alpha=5$ persen diperoleh nilai $\mathrm{d}_{l}=1,378$ dan $\mathrm{d}_{u}=1,721$. Jika dibandingkan ternyata nilai $\mathrm{d}>\mathrm{d}_{u}$, dengan demikian data yang diolah tersebut tidak menunjukkan adanya gejala autokorelasi, 
dan nilai VIF kurang dari 5, dengan demikian data yang diolah menunjukkan kecilnya gejala multikolinieritas.

\section{c. Pengujian Hipotesis}

Berdasarkan hasil analisis regresi linier berganda didapatkan hasil yang disajikan pada tabel 1, 2 dan berikut:

Tabel 1

Model Summary

\begin{tabular}{|l|l|l|l|l|l|}
\hline Model & $\mathrm{R}$ & R Square & $\begin{array}{l}\text { Adjusted R } \\
\text { Square }\end{array}$ & $\begin{array}{l}\text { Std. Error of } \\
\text { the Estimate }\end{array}$ & Durbin-Watson \\
\hline 1 & .547 & .299 & .261 & 2.62047 & 1.823 \\
\hline
\end{tabular}

a. Predictors: (Constant), X5, X4, X1, X2, X3

b. Dependent Variable: $Y$

Tabel 2.

ANOVA $^{b}$

\begin{tabular}{|l|l|l|l|l|l|l|}
\hline \multicolumn{2}{|l|}{ Model } & $\begin{array}{l}\text { Sum of } \\
\text { Squares }\end{array}$ & df & Mean Square & F & Sig. \\
\hline \multirow{3}{*}{1} & Regression & 269.230 & 5 & 53.846 & 7.841 & $.000^{\mathrm{a}}$ \\
\cline { 2 - 8 } & Residual & 631.750 & 92 & 6.867 & & \\
\cline { 2 - 8 } & Total & 900.980 & 97 & & & \\
\hline
\end{tabular}

a. Predictors: (Constant), X5, X4, X1, X2, X3

Table 3

Coefficients ${ }^{a}$

\begin{tabular}{|c|c|c|c|c|c|c|}
\hline \multirow{2}{*}{\multicolumn{2}{|c|}{ Model }} & \multicolumn{2}{|c|}{$\begin{array}{l}\text { Unstandardized } \\
\text { Coefficients }\end{array}$} & \multirow{2}{*}{$\begin{array}{l}\text { Standardized } \\
\text { Coefficients } \\
\text { Beta } \\
\end{array}$} & \multirow[b]{2}{*}{$t$} & \multirow[b]{2}{*}{ Sig. } \\
\hline & & B & Std. Error & & & \\
\hline \multirow[t]{6}{*}{1} & $\begin{array}{l}\text { (Constan } \\
\text { t) }\end{array}$ & 12.402 & 1.800 & & 6.891 & .000 \\
\hline & $\mathrm{X} 1$ & .288 & 0.0830 & 0.246 & 3.46987 & 0.025 \\
\hline & $\mathrm{X} 2$ & .302 & 0.0895 & 0.318 & 3.37430 & 0.045 \\
\hline & $\mathrm{X} 3$ & .400 & 0.0525 & 0.213 & 4.95121 & 0.019 \\
\hline & $\mathrm{X} 4$ & .235 & 0.0695 & 0.270 & 3.38129 & 0.036 \\
\hline & $\mathrm{X} 5$ & .170 & 0.0395 & 0.232 & 4.30379 & 0.014 \\
\hline
\end{tabular}

Dari tabel 1 di atas diperoleh nilai $\mathrm{F}$ tabel=4,734 dengan tingkat signifikan 0.025 hal ini membuktikan bahwa secara bersama-sama variable iklim organiasi, perilaku pimpinan, motivasi kerja, dan praktek pengambilan keputusan secara simultan mempunyai pengaruh yang signifikan terhadap terhahap kepuasan kerja karyawan Pada PT. Asam Jawa Medan pada $\alpha=5$ persen. variable iklim organiasi, perilaku pimpinan, motivasi kerja, dan praktek pengambilan keputusan mampu menjelaskan variasi terhahap kepuasan kerja karyawan sebesar 29,99 persen sedangkan sisanya 70,01 persen oleh variabel lainnya. Dari Tabel 3 di atas nampak 
bahwa variable iklim organiasi, perilaku pimpinan, motivasi kerja, dan praktek pengambilan keputusan masing-masing secara parsial mempunyai pengaruh positif dan signifikan terhadap kepuasan kerja karyawan PT. Asam Jawa Medan hal ini ditunjukkan dari masing-masing $t$ hitung 3,4698, 3,3743, 2,9512, 3,3813 dan 4,3038 dengan tingkat signifikan dibawah 5 persen.

\section{Pembahasan}

Penelitian ini membuktikan bahwa secara simultan dan parsial variable iklim organiasi, perilaku pimpinan, motivasi kerja, dan praktek pengambilan keputusan secara simultan mempunyai pengaruh yang signifikan terhadap terhahap kepuasan kerja karyawan Pada PT. Asam Jawa Medan. Hal ini membuktikan bahwa untuk meningkatkan kepuasan kerja karyawan perlu memperbaiki iklim organiasi, perilaku pimpinan, motivasi kerja, dan praktek pengambilan keputusan

Kesimpulan

\section{KESIMPULAN DAN SARAN}

Iklim organiasi, perilaku pimpinan, motivasi kerja, dan praktek pengambilan keputusan secara simultan dan parsial mempunyai pengaruh yang signifikan terhadap kepuasan kerja karyawan

Saran

Bagi perusahaan dalam meningkatkan kepuasan karyawan hendaknya memperbaikai iklim organiasi, perilaku pimpinan, motivasi kerja, dan praktek pengambilan keputusan

\section{DAFTAR PUSTAKA}

Adenike, A., 2011. Organizational Climate as a Predictor of Employee Job Satisfaction: Evidence from Covenant University. Business Intelligence Journal. Vol : 4 No.1

Arinez, A., Bouzidi, M., Koo, B., Sayeed, A., Serenata, C., Suarez, E. \& Sulaiman, A.B. 2002. Creating a Work Climate That Motivates Staff and Improves Performance. The Manager Journal. Vol 11. Number 3.

Davidson, M., Manning, M., Timo, N. \& Ryder, P. 2001. The Dimensions of Organizational Climate In Four and Five Star Australian Hotels. Journal of Hospitality \& Tourism Research. Vol 25, No 4. Page $444-461$.

Gibson, Ivannevich dan Donnelly. (1996). Organisasi. Perilaku struktur proses jilid 1 edisi kedelapan alih bahasa: Nunuk Adiarni. Jakarta. Binapura Aksara

Gibson, J.L., Ivancevich, J.M. dan Donnelly, J.H. 2002. Perilaku Organisasi, Struktur dan Proses. Penerjemah : Nunuk Adiarni. Tangerang : Binarupa Aksara.

Hasibuan, M.S.P. (2005). Organisasi dan Motivasi: Dasar prningkatan produk. Jakarta: Bumi Aksara.

Pace, R Wayne, Don F Faules. (1994). Organizational Communication. 3rd Edition, New Jersey: Prentice Hall. 
Prabu, A., 2005. Pengaruh Motivasi Terhadap Kepuasan Kerja Pegawai Badan Koordinasi Keluarga Berencana Nasional Kabupaten Muara Enim. Jurnal Manajemen \& Bisnis Sriwijaya. Vol 3. No 6.

Singh, R. R., Chauhan. A., Agrawal. S. dan Kapoor. S. 2011. Impact Of Organisational Climate On Job satisfaction A - Comparative study. International Journal of Computer Science and Management Studies. Vol 11. Issue 02.

Soetopo, H., 2010. Perilaku organisasi. Bandung : PT Remaja Rosdakarya.

Sopiah. 2008. Perilaku organisasional. Yogyakarta : CV. Andi.

Tella, A., Ayeni, C.O. dan popoola, S.O. 2007. Work motivation, job satisfaction, and organization commitment of library personnel in academic and research libraries in oyo state, Nigeria. Journal of Psychology.

Wilson, G. V. 2005. The Effects of External Rewards on Intrinsic Motivation. Intrinsic Motivation.

Wirawan. 2007. Budaya dan Iklim Organisasi. Jakarta: Salemba Empat. 